\title{
Predictors of seatbelt and helmet usage among victims seeking care at emergency department in a tertiary care hospital in rural Northern India.
}

\author{
Chaudhary C, ${ }^{1 *}$ Singh $A,{ }^{1}$ Pathak $R,{ }^{1}$ Ahluwalia SK, ${ }^{1}$ Goel RKD, ${ }^{1}$ Mithra P $^{2}$ \\ ${ }^{1}$ Department of Community Medicine, Maharishi Markandeshwar Institute of \\ Medical Sciences and Research (MMIMSR), Mullana (Ambala), Haryana, India, \\ ${ }^{2}$ Department of Community Medicine, Kasturba Medical College (KMC) Mangalore, India
}

\author{
*Corresponding Author: \\ Dr. Chintu Chaudhary \\ Resident, Department of Community Medicine \\ Address- D-72, Sector-9, New Vijay Nagar, Ghaziabad. \\ 201009, Uttar Pradesh, India \\ E mail: chaudharychintu@gmail.com

\section{Citation} \\ Chaudhary C, Singh A, Pathak R, Ahluwalia SK, Goel \\ RKD, Mithra P. Predictors of seatbelt and helmet usage \\ among victims seeking care at emergency department \\ in a tertiary care hospital in rural Northern India. Nepal \\ Journal of Medical Sciences 2013;2(1):57-61.
}

\begin{abstract}
Background: Despite the introduction of seat belt and helmet legislation their use in India is still not satisfactory. The present study was therefore conducted to assess the prevalence of and factors associated with safety belt and helmet non-use among Emergency Department (ED) patients seeking care at a tertiary care teaching hospital.
\end{abstract}

Methods: The present cross sectional study with systematic sampling was carried out among stable, non-urgent ED patients aged more than 18 years using pretested questionnaire during July to December 2011. Safety belt use was defined via two methods: a single-item and a multiple-item measure of safety belt use.

Results: Outcome for multivariate logistic regression analysis was safety belt use less than 'always'. Of 350 patients approached, 280 (80\%) participated. The prevalence of safety belt/helmet use 'always' was $31 \%$ and $16 \%$ respectively using two different survey measures. Male gender, maximum alcohol consumption of greater than 5 drinks in a single episode, riding with others that drink and drive, ever receiving a traffic citation for not wearing a safety belt or helmet, the belief that safety belt use is "uncomfortable", and that "I just forget to use my seatbelt" were risks for safety belt non-use according to the Single Measure of Safety Belt/ Helmet Use, while "it's my usual habit" was protective.

Conclusion: Findings of the study warrants urgent need to take measures or targeted interventions in order to increase safety belt and helmet use among this high risk population.

Keywords: Seat Belt; Helmet; Rural; Predictors.

\section{Background:}

$\mathbf{R}$ oad Traffic accidents (RTAs) have emerged as a major global public health problem and are now recognised as "veritable neglected pandemic". 1,2 These preventable injuries are a major cause of cognitive and functional impairment, resulting in significant financial losses to both individuals and society. ${ }^{3}$ The problem is so severe that, by 2020 , it is projected that road traffic disability-adjusted life years (DALYs) lost will move from being the 9th leading cause of DALYs lost to the 3rd leading cause in the world and will be 2 nd leading cause in developing countries. In 
2009, 4.22 lakh RTAs and 1.27 lakh road traffic fatalities were reported. ${ }^{4}$

RTAs are a major public health problem in India despite the introduction of seat belt and helmet legislation. ${ }^{5}$ India will witness minimum 185,000 deaths and 3.6 million hospitalizations by 2015 . Today, motor vehicle injuries are next only to cardiovascular disease in terms of the public health burden and impact. ${ }^{6}$ In 20 years; there will be a $65 \%$ increase, mainly in developing countries. ${ }^{7}$ Global road fatalities are expected to touch figure of 1.9 million by 2020. The average cost of motor vehicle injuries in India is approximately \$US12.5 million (Rs.7 lakh crores). ${ }^{8}$

Seat belt and helmet usage has saved more lives than any other road safety intervention and its efficacy in the reduction of mortality from RTAs by $25-67 \%$ has been well documented. ${ }^{9-11}$ The relative paucity of studies related to the correlates of the safety belt and helmet usage among Emergency Department (ED) patients in India also warrants this study. The present study was therefore conducted to assess the prevalence of and factors associated with safety belt and helmet non-use among ED patients seeking care at a tertiary care teaching hospital in rural Northern India.

\section{Methods:}

The present descriptive cross sectional study was carried out among stable, non-urgent ED patients (i.e. patients not triaged to the acute area of the ED) aged more than 18 years seeking care at Maharishi Markandeshwar Institute of Medical Sciences And Research (MMIMSR), Haryana using pretested self administered questionnaire. All adult stable non-urgent ED patients presenting between $1^{\text {st }}$ July to $31^{\text {st }}$ December 2011 and who were able to provide verbal informed consent for this hospital based survey, were eligible for participation in the study.

Those patients unable to provide verbal consent (including those experiencing altered mental status due to drug/alcohol intoxication, injury, or acute psychiatric illness); in severe pain or distress; deemed too ill to be interviewed by the ED staff (i.e., major trauma or medical illnesses) were excluded from the study. Permission from Institutional Review Board was sought before the commencement of the present study.

The systematic sampling method consisted of researchers walking clockwise from room-to-room in the ED, sampling every patient to identify those that met enrolment criteria. If a patient met enrolment criteria, they were requested to participate in the study. In case a patient did not meet criteria, or refused to participate, researchers went to the next sequential room. Questions were read to them and their responses were captured by the researchers. The survey generally required 5 to 6 minutes to complete.

A detailed questionnaire was framed for the purpose of capturing socio-demographic information of the study participants, frequency of riding in automobiles, frequency and correlates of safety belt use and safety belt non-use (e.g., listing items under the heading, 'things that make me wear my seat belt' and 'things that make me not wear my seat belt'), and frequency of alcohol consumption. The questionnaire was designed in English initially and later translated in Hindi and retranslated to English to check validity of questions contained. Safety belt and helmet use were determined by two methods, using a single and multiple global measures of safety belt and helmet use. Participants were requested to respond to single question based on a 5-point scale in single global measures of safety belt and helmet use. To minimize the effects of over-reporting in our study, safety belt use was also assessed by a series of nine separate questions (the Multiple Measure of Safety Belt Use) on scenario-specific aspects of transportation (highway, local, daytime, nighttime, driver, front-seat passenger, backseat passengers, short distance rides, and long distance rides).

After compilation of collected data analysis was done using SPSS version 11.5. Interpretation of the collected data was done by using appropriate statistical methods and tests like chi-square test, univariate and multivariate logistic regression.

\section{Results:}

\section{Profile of study subjects}

Of 350 patients approached, 280 participated giving an overall response rate of $80 \% .218(77.85 \%)$ of the respondents were male while $62(22.15 \%)$ were female. $82 \%$ were from rural background. The median age of the participants was 35 years.

The association between demographic characteristics of study subjects and responses to the Single Measure and the Multiple Measure of Safety Belt Use is shown in table 1. Using two different survey measures, a single-item and a multiple-item measure, safety belt/helmet use 'always' was $31 \%$ and $16 \%$ respectively. Gender and education were significantly associated with a response of 'always' wearing a safety belt or helmet $(\mathrm{p}<0.05)$. 
Table 1: Socio-demographic profile of study subjects with responses to single and multiple measures of safety belt and helmet use.

\begin{tabular}{|c|c|c|c|c|c|}
\hline Variable & $\begin{array}{c}\text { Total } \\
\text { Sample } \\
\text { N (\%) }\end{array}$ & $\begin{array}{c}\text { SBHU 'Always', by } \\
\text { Single Measure } \\
\text { Use N (\%) }\end{array}$ & $\begin{array}{c}P \\
\text { value }\end{array}$ & $\begin{array}{c}\text { SBHU 'Always', by } \\
\text { Multiple Measure } \\
\text { Use N (\%) }\end{array}$ & $\begin{array}{c}P \\
\text { value }\end{array}$ \\
\hline \multicolumn{6}{|c|}{ Gender } \\
\hline Male & $218(77.5)$ & $56(64.3)$ & \multirow{2}{*}{$<0.05$} & $20(44.4)$ & \multirow{2}{*}{$<0.001$} \\
\hline Female & $62(22.1)$ & $31(35.6)$ & & $25(55.5)$ & \\
\hline \multicolumn{6}{|c|}{ Age } \\
\hline $18-23$ yrs & $59(21.0)$ & $17(19.5)$ & \multirow{4}{*}{0.763} & $10(22.2)$ & \multirow{4}{*}{0.08} \\
\hline $24-29$ yrs & $105(37.5)$ & $19(21.8)$ & & $11(24.4)$ & \\
\hline $30-35$ yrs & $76(27.1)$ & $29(33.3)$ & & $13(28.9)$ & \\
\hline$>35 \mathrm{yrs}$ & $40(14.2)$ & $22(25.3)$ & & $11(24.4)$ & \\
\hline \multicolumn{6}{|c|}{ Education } \\
\hline Noeducation & 35 (12.5) & $5(5.7)$ & \multirow{4}{*}{$<0.05$} & $2(4.2)$ & \multirow{4}{*}{$<0.05$} \\
\hline Primary & $41(14.6)$ & $9(10.3)$ & & $5(10.6)$ & \\
\hline Secondary & $118(42.1)$ & $41(47.1)$ & & $16(34.0)$ & \\
\hline $\begin{array}{l}\text { Graduation } \\
\text { andabove }\end{array}$ & 86 (30.7) & $32(36.7)$ & & $24(51.0)$ & \\
\hline
\end{tabular}

History of being in a car crash, driving after drinking, receiving a citation for not wearing a safety belt or helmet, as well as the quantity of alcohol use were found to be associated with safety belt or helmet use (Table 2).

Table 2: Distribution of subjects according to responses related to safety belt or helmet use.

\begin{tabular}{|c|c|c|c|c|c|}
\hline Variable & $\begin{array}{c}\text { Total } \\
\text { Sample } \\
\text { N (\%) }\end{array}$ & $\begin{array}{l}\text { SBHU 'Always', } \\
\text { by Single } \\
\text { Measure N (\%) }\end{array}$ & $P$ value & $\begin{array}{l}\text { SBHU 'Always', } \\
\text { by Multiple } \\
\text { Measure N (\%) }\end{array}$ & $P$ value \\
\hline
\end{tabular}

Ever been in crash?

$\begin{array}{lllrl}\text { Yes } & 182(65) & 75(55.1) & <0.001 & 51(56.6) \\ \text { No } & 98(35) & 61(44.8) & 39(43.3) & 0.15\end{array}$

Driving after drinking (in past 30 days)?

$$
\begin{array}{llllll}
\text { Yes } & 48(17.1) & 10(6.3) \\
\text { No } & 232(82.8) & 115(73.2) & 0.008 & \begin{array}{l}
6(6.9) \\
81(93.1)
\end{array} & 0.04
\end{array}
$$

Ride with someone who drove after drinking (in past 30 days)?

$$
\begin{array}{llllll}
\text { Yes } & 58(20.7) & 20(13.9) & 0.07 & 11(16.1) & 0.08 \\
\text { No } & 222(79.2) & 123(86.0) & & 57(83.8) &
\end{array}
$$

Ever received a citation for not wearing seatbelt/ helmet?

$\begin{array}{llllll}\text { Yes } & 33(11.7) & 12(8.5) & 0.05 & 5(6.2) & 0.045 \\ \text { No } & 247(88.3) & 128(91.4) & & 75(93.7) & \end{array}$

On average, how many drinks do you have on a typical day?

\begin{tabular}{lllll} 
0-1drinks $70(25)$ & $32(28.8)$ & & $18(30.0)$ & \\
2-5drinks $168(60)$ & $67(60.4)$ & 0.002 & $35(58.3)$ & 0.001 \\
$\begin{array}{l}\text { 6ormore } \\
\text { drinks }\end{array}$ & $42(15)$ & $12(10.8)$ & $7(11.6)$ & \\
\hline
\end{tabular}

SBHU $=$ Seat belt and helmet use
Male gender, maximum alcohol consumption of greater than 5 drinks in a single episode, riding with others that drink and drive, ever receiving a traffic citation for not wearing a safety belt or helmet, the belief that safety belt use is "uncomfortable", and that "I just forget to use my seatbelt" were risks for safety belt non-use according to the Single Measure of Safety Belt/ Helmet Use, while "it's my usual habit" was protective (Table 3 ).

According to the Multiple Measure of Safety Belt/ Helmet Use, male gender, riding with others that drink and drive, being given a traffic citation for not wearing a safety belt or helmet, the belief "wearing a seatbelt/ helmet is uncomfortable", that "I've got too many other things to think about", and "I just forget to use my seatbelt/helmet" were risks for safety belt/helmet non-use. Once again, a response that safety belt/helmet use is a usual habit was protective against non-use (Table 3 ).

Table 3: Prediction of risk factors for Seat Belt or Helmet

\begin{tabular}{|c|c|c|c|c|c|c|}
\hline \multirow{2}{*}{ Variable } & \multicolumn{3}{|c|}{$\begin{array}{c}\text { Single Measure of } \\
\text { Safety Belt/ Helmet Use }\end{array}$} & \multicolumn{3}{|c|}{$\begin{array}{c}\text { Multiple Measure of } \\
\text { Safety Belt/ Helmet Use }\end{array}$} \\
\hline & $\begin{array}{l}\text { Odds } \\
\text { Ratio }\end{array}$ & Pvalue & 95\% C.I. & $\begin{array}{l}\text { Odds } \\
\text { Ratio }\end{array}$ & $\begin{array}{c}\mathrm{P} \\
\text { value }\end{array}$ & 95\% C.I. \\
\hline Male Gender & 2.53 & .007 & $1.19-3.78$ & 2.23 & 0.04 & $1.43-4.15$ \\
\hline $\begin{array}{l}\text { I just forget to } \\
\text { wearmyseatbelt/ } \\
\text { helmet* }\end{array}$ & 2.89 & .005 & $1.44-3.39$ & 3.34 & $<0.001$ & $1.98-4.33$ \\
\hline $\begin{array}{l}\text { Rideswithothers } \\
\text { who drink and } \\
\text { drive }\end{array}$ & 3.44 & .009 & $1.66-5.51$ & 2.61 & 0.03 & $1.54-5.56$ \\
\hline $\begin{array}{l}\text { Ever received a } \\
\text { ticketfornotwearing } \\
\text { a seatbelt/ helmet }\end{array}$ & 3.91 & .004 & $1.61-6.08$ & 2.83 & 0.04 & $2.10-6.06$ \\
\hline $\begin{array}{l}\text { Maximumalcohol } \\
\text { consumptionSingle } \\
\text { Episode }>5 \text { drinks }\end{array}$ & 3.12 & .03 & $1.24-5.55$ & 4.38 & $<0.001$ & $2.64-4.81$ \\
\hline $\begin{array}{l}\text { Wearing a } \\
\text { seatbelt/helmet } \\
\text { is a usual habit* }\end{array}$ & 0.04 & $<0.001$ & $0.01-0.11$ & 0.12 & 0.001 & $1.18-2.24$ \\
\hline $\begin{array}{l}\text { Wearing a } \\
\text { seatbelt/helmet } \\
\text { isuncomfortable* }\end{array}$ & 3.86 & $<0.001$ & $2.23-6.09$ & 2.85 & 0.05 & $2.67-5.50$ \\
\hline
\end{tabular}
non-use using multivariate logistic regression analysis.

\section{Discussion:}

Wearing seat belts or helmets by occupants of moving vehicles are believed to have saved millions of lives 
worldwide. Wearing of seat belt/helmet is mandatory and the most important precaution one can take to minimize risk in an accident. ${ }^{12}$ According to a single-item query, the prevalence of consistent safety belt use was 31\%; though using a Multiple Measure, safety belt use was only $16 \%$ in our study. Another study from Boston University reported prevalence of safety belt use 'always' was 51\% and $36 \%$ respectively using two different survey measures, a singleitem and a multiple-item. ${ }^{13}$

The present study revealed that, least use of helmets/seatbelts was in the age group of 18 to 23 years $(21.07 \%)$. Tendency of this particular age group to show scarce attention to traffic rules can be a possible explanation for the same. In a hospital based study by Ganveer GB, majority of the victims were in the age group 18-37 years. ${ }^{14}$

In the present study we used two methods to estimate overall safety belt use a commonly used measure, the Single Measure, and a multi-item Multiple Measure of Safety Belt Use. Use of the single global measure can overestimate observed safety belt use ${ }^{15}$ so; we used a Multiple Measure of Safety Belt Use that, by design, was a more stringent measure of self-reported safety belt use.

In the present study it was observed that, male gender, increased alcohol consumption, riding with others that drink and drive, being cited for not wearing a safety belt, the belief that safety belt use is 'uncomfortable', that 'I just forgot', factors were associated with safety belt non-use, while reporting that 'safety belt use is my usual habit' was protective of non-use.

According to multiple measure of safety belt/helmet use, females were more likely than males to report that they always wear a seat belt. Similar observations were also made by others. ${ }^{16}$ On the other hand, according to single measure of safety belt/helmet use, males reported more than females that they always wear a seat belt or helmet. The current study contradicts the observation of another study from Spain ${ }^{17}$ on this particular aspect. This could be due to the fact that in developing countries like India females are less exposed to streets hence less opportunity to use safety belt/ helmets. This can again be supported by the fact that males outnumbered females as study subjects.

Not surprisingly our study shows that individuals drinking and driving in the past 30 days were less likely to wear seat belts. Other author ${ }^{18}$, have also noted that excessive alcohol use is correlated with other high-risk behaviours, including seat belt and helmet non-use. An epidemiological study of RTA conducted by Singh A et al, ${ }^{1}$ reported that consumption of alcohol is an antecedent factor for risky behaviour leading to RTA. Another study regarding seatbelt use in American Indian motor vehicle crash trauma victims reported that low seatbelt use by American Indian's on the reservation was primarily associated with alcohol use. ${ }^{19}$

One evident limitation of this study is a direct consequence of its study population i.e. clinical population, which may not allow us to generalize our findings to the general population. Clinical populations tend to differ from population-based samples in terms of several factors. It is a proven fact that ED patients have higher injury-prone behaviours than other clinical population. ${ }^{20}$ Secondly, possibility of volunteer bias cannot be ruled out. Thirdly, there may have been a response bias resulting from researchers asking the survey questions in a face-to face interview instead of having participants complete a self-reported survey.

\section{Conclusion:}

To conclude, findings of the present study demonstrates that ED patients at a tertiary care hospital in Northern India have reported safety belt and helmet use which is relatively low. Hence there is an urgent need to take measures or targeted interventions in order to increase safety belt and helmet use among this high risk population.

\section{Conflicts of interests: None}

\section{References:}

1. Singh A, Bhardwaj A, Pathak R, et al. An epidemiological study of road traffic accident cases at a tertiary care hospital in rural Northern India. Indian Journal of Community Health 2011; 23:53-55.

2. Dandona R, Mishra A. Deaths due to road traffic crashes in Hyderabad city in India: Need for strengthening surveillance. Natl Med J India 2004;17:74-9.

3. Michaels AJ, Michaels CE, Smith JS, et al. Outcome from injury: general health, work status, and satisfaction 12 months after trauma. J Trauma 2000;48:841-8.

4. Murray CJL, Lopez AD: Alternative projections of mortality and disability by cause 1990-2020: Global Burden of Disease Study. The Lancet 1997;349:1498-504.

5. Motor Vehicles Act, Ministry of Road Transport and Highways (MoRTH), Government of India. Available from; URL: http://morth.nic.in 
6. Health and road traffic accidents. Available from; URL: www.unescap.org/ttdw/common/TIS/AH/files/.../ roadsafety india.pdf

7. Crandon IW, Harding HE, Branday JM, et al. The prevalence of seat belt use in Kingston, Jamaica: a follow-up observational study five years after the introduction of legislation. West Indian med $\mathrm{j}$ 2006;55:327-9.

8. Rajasekaran S. Indian Orthopaedic Association. The Alarming Facts of Road Accidents in India. Available from; URL: www.ioaindia.org/ ROADTRAFFICACCIDENTS.pdf

9. World Health Organization (WHO) and the World Bank report. World report on road traffic injury prevention 2004. Available from; http://www.who.int/worldhealth-day/2004/en.

10. Rutledge R, Lalor A, Oller D, et al. The cost of not wearing seat belts. A comparison of outcome in 3396 patients. Ann Surg 1993; 217: 122-7.

11. El-Sadig M, Sarfraz-Alam M, Carter AO, et al. Evaluation of effectiveness of safety seat belt legislation in the United Arab Emirates. Accid Anal Prev 2004;36: 99-404.

12. Road Accidents in India, 2009. Transport Research Wing, Ministry of Road Transport and Highways, Government Of India, New Delhi.

13. Fernandez WG, Mehta SD, Coles T, et al. Selfreported safety belt use among emergency department patients in Boston, Massachusetts. BMC Public Health 2006;6:111-21.

14. Ganveer GB, Tiwari RR. Injury Pattern among nonfatal Road Traffic Accident cases: a cross sectional study in central India. Indian J Med Sci 2005;59: 9-12.

15. Dee TS. Reconsidering the effects of seat belt laws and their enforcement status. Accid Anal Prev 1998, 30:1-10.

16. Shinar D, Schechtman E, Compton R. Self-reports of safe driving behaviors in relationship to sex, age, education and income in the US adult driving population. Accid Anal Prev 2001;33:111-6.

17. Babio GO, Daponte CA. Factors associated with seatbelt, helmet, and child safety seat use in a spanish high-risk injury area. J Trauma 2006 ;60:620-6.

18. Baker DR, Clarke SR, Brandt EN Jr. An analysis of factors associated with seat belt use: prevention opportunities for the medical community. J Okla State Med Assoc 2000;93:496-500.

19. Gross EA, Axberg A, Mathieson K. Predictors of seatbelt use in American Indian motor vehicle crash trauma victims on and off the reservation. Accid Anal Prev 2007;39:1001-5.

20. Lowenstein SR, Koziol-McLain J, Thompson M, et al. Behavioural risk factors in emergency department patients: a multisite survey. Acad Emerg Med 1998;5:781-7. 